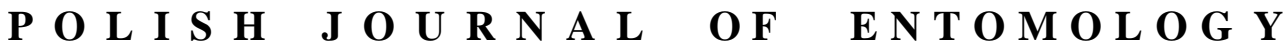

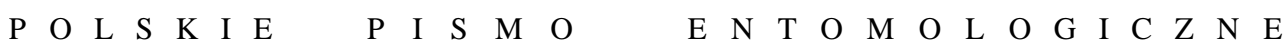

VOL. 84: 191-200

Lublin

30 September 2015

DOI: $10.1515 /$ pjen-2015-0016

\section{Ceraphronidae and Megaspilidae (Hymenoptera: Ceraphronoidea) of Poland: current state of knowledge with corrections to the Polish checklist}

\author{
MACIEJ KRZYŻYŃSKI ${ }^{1}$, WERNER ULRICH ${ }^{2}$
}

Nicolaus Copernicus University, Chair of Ecology and Biogeography, Lwowska 1, 87-100 Toruń, Poland, e-mail: ${ }^{1}$ m_krzy@doktorant.umk.pl, ${ }^{2}$ ulrichw@umk.pl

\begin{abstract}
An updated checklist of 16 Ceraphronoidea (Hymenoptera, Parasitica) species from Poland is given together with information on deposition, sampling, and, if possible, host associations. We also present a complete reference list regarding work on Polish Ceraphronoidea.
\end{abstract}

KEY WORDS: Ceraphronoidea, Ceraphronidae, Megaspilidae, check list.

\section{INTRODUCTION}

The superfamily Ceraphronoidea, containing the families Ceraphronidae and Megaspilidae, is surely the least known higher taxon among the Hymenoptera as documented in the recent catalogue by JOHNSON (2015). First established by HALIDAY (1833) as a family, revised by KIEFFER (1914), and given superfamily status by MASNER \& DESSART (1967), the taxonomy of the superfamily is still in its infancy. Newer keys to the European genera and species by HELLÉN (1966), DESSART (1987) and ALEKSEEV (1978) clarified the species status of a number of species and added species to the European fauna. KIEFFER (1914) listed 106 European species of Ceraphronidae and 188 species of Megaspilidae. DESSART (1987) reviewed and described an additional 97 Ceraphronidae and 78 Megaspilidae, while ALEKSEEV (1978) mentioned 58 Ceraphronidae and 56 Megaspilidae for the Palaearctic.

The most recent compilation of Fauna Europaea (POLASZEK 2015) lists 224 described species (102 Ceraphronidae and 140 Megaspilidae) for Europe, even though in many cases their species status remains unconfirmed. However, the number of recorded species has 
surely been seriously underestimated. Based on European species-area relationships and his own collections, ULRICH (1999) estimated the number to be at least 400 species.

The most resent checklist by GARBARCZYK (1997) lists 12 species of Ceraphronoidea from Poland, while BANASZAK et al. (2000) estimated that there were about 70 species of Ceraphronidae and about 45 species of Megaspilidae. In the light of the local data of UlRICH $(2001,2005)$, who found 46 species of Ceraphronoidea in a German beech forest and as many as 37 species on an adjacent small meadow on limestone, these figures for the Polish fauna appear to be gross underestimations. The latest faunistic data from the Czech Republic (ZEMAN \& VANĚK 1999) list six species of Ceraphronoidea not recorded in Poland: Ceraphron pedes FÖRSTER, 1861, C. squamiger KIEFFER, 1907, Dendrocerus liebscheri DESSART, 1972, D. solarii (KIEFFER, 1907), Conostigmus obscurus (THOMSON, 1859) [as C. arcticus (THOMSON, 1859)] and Lagynodes thoracicus KIEFFER, 1906 (as L. thoracius). Since sampling took place close to the Polish border, we can assume with confidence that these species are also part of the Polish fauna. HELLÉN (1966) mentioned 38 species of Ceraphronidae and 35 species of Megaspilidae. Although his list might contain a number of synonyms, and identifications are not always reliable, many of the Finnish species should also occur in Poland. Applying UlRICH's $(1999,2001)$ species-area relationships, we conservatively assume the true species number in Poland to be well above 200.

Our knowledge about the Ceraphronoid species range sizes, their hosts, and their ecology is similarly poor (cf. MIKÓ \& DEANS 2009). Hosts are known for only a very small number of species, particularly from the genus Dendrocerus RATZEBURG, 1852. Most Dendrocerus species are aphid hyperparasitoids but have also been reared from Neuroptera, and aphid predators. For instance, D. pupparum (BOHEMAN, 1832) is a parasitoid of the aphidophagous hoverflies Syrphus ribesii (LINNAEUS, 1758) and Episyrphus balteatus (DE GEER, 1776) (Diptera: Syrphidae) (FERGUSSON 1980). Lagynodes pallidus (BOHEMAN, 1829 ) is a secondary parasitoid of Braconidae in lepidopteran larvae (KARCZEWSKI 1962, DESSART 1987). Some Aphanogmus (THOMSON, 1858) species attack predatory (PSCHORNWALCHER 1956, OATMAN 1985) and gall-inducing (PARNELL 1963) cecidomyiid larvae, cybocephalid Coleoptera (EvANS et al. 2005), coniopterygid Neuroptera (PRIESNER 1960), and Thysanoptera (DESSART \& BOURNIER 1971). An American species of Conostigmus (DAHLBOM, 1858) was reared from Mecoptera (COOPER \& DESSART 1975), while LUHMAN et al. (1999) reported this species being reared from Trichoptera (reviewed in MiKó \& DEANS 2009, BROAD \& LIVERMORE 2014). Based on emergence trap samples ULRICH (2005) speculated that many species might develop in nematoceran larvae (Diptera) associated with soil microhabitats. Ceraphronid species of the Polish fauna have been reared from gall-inducing Cecidomyiidae (GARBARCZYK 1997) and found to be associated with plant fruits, although most rearing and host identifications needs confirmation. 
Astonishingly, the few available quantitative assessments of Ceraphronidae and Megaspilidae (except for the genus Dendrocerus) abundances revealed high local densities of several tens to even hundreds of individuals per square metre emerging from forest floors (UlRICH 2001) and open landscapes (SCHMITT 2004, ULRICH 2005). These densities are comparable to those of related and better studied hymenopteran taxa like Braconidae, Ichneumonidae or Diapriidae (UlRICH 2001, 2005). These observed densities also indicate high host densities, a fact that greatly reduces the range of possible hosts to abundant Diptera, Hemiptera and possibly Coleoptera.

The present study is a first step towards a better knowledge of Polish Ceraphronoidea. We present faunistic and, if available, ecological information on 16 ceraphronoid species (12 Ceraphronidae and 4 Megaspilidae) so far recorded from Poland.

\section{MATERIALS AND METHODS}

From a literature review and examination of material deposed in the Museum and Institute of Zoology of the Polish Academy of Sciences in Warsaw (MIZ) we have updated and amended the checklist of Polish Ceraphronoidea (GARBARCZYK 1997) that contains nine species of Ceraphronidae and three species of Megaspilidae without giving details regarding identification, deposition and references. With regard to nomenclature and synonyms, we follow the Hymenoptera Name Server (http://osuc.biosci.ohio-state.edu/).

We examined one specimen of Lagynodes pallidus from the KARCZEWSKI collection in MIZ owing to its doubtful original identification. We used the key of ALEKSEEV (1978) and a Leica M2015C microscope with camera. Below, species not given in GARBARCZYK (1997) are labelled with an asterisk (*).

\section{RESULTS}

\section{CERAPHRONIDAE}

Ceraphron bispinosus (NEES VON ESENBECK, 1834)

Skierniewice, Łódź Province [as $C$. striatus FöRSTER, 1861]: one specimen found in an apple orchard (OLSZAK 1992).

\section{Ceraphron cursor KIEFFER, 1907}

Skierniewice, Łódź Province: three specimens found on Sambucus nigra LinNaEus, 1753 bordering an apple orchard (OLSZAK 1992). 


\section{Ceraphron sulcatus JURINE, 1807}

Skierniewice, Łódź Province: one specimen found on Sambucus nigra bordering an apple orchard (OLSZAK 1992).

\section{Aphanogmus abdominalis (THOMSON, 1859) *}

Wolica, Mazowsze Province: 12 specimens parasitizing Dasineura brassicae WinNERTZ, 1853 larvae (Diptera: Cecidomyiidae) (CZAJKOWSKA 1978).

\section{Aphanogmus fulmeki SZELÉNYI, 1940}

Forest Inspectorate of Brzesko, Małopolska Province: two specimens reared from Larix decidua MILLER, 1768 cones, parasitizing an Asynapta laricis SKRZYPCZYŃSKA, 1977 larvae (Diptera: Cecidomyiidae) (SKRZYPCZYŃSKA 1978).

\section{Aphanogmus gracilicornis FÖRSTER, 1861}

Wielkopolska National Park, Wielkopolska Province: one specimen reared from a Larix decidua cone, parasitizing an Asynapta laricis larva (Diptera: Cecidomyiidae) (SKRZYPCZYŃSKA 1974).

Muszyna, Małopolska Province: one specimen reared from a Larix decidua cone, parasitizing an Asynapta laricis larva (Diptera: Cecidomyiidae) (SKRZYPCZYŃSKA 1974).

\section{Aphanogmus nanus (NEES VON ESENBECK, 1834)}

Skierniewice, Łódź Province [as Ceraphron nigriceps (THOMSON, 1858)]: one specimen found on Sambucus nigra bordering an apple orchard (OLSZAK 1992).

\section{Aphanogmus steinitzi PRIESNER, 1936}

Wielkopolska National Park, Wielkopolska Province: one specimen reared from a Larix decidua cone, parasitizing an Asynapta laricis larva (Diptera: Cecidomyiidae) (SKRZYPCZYŃSKA 1978).

Leżajsk, Podkarpackie Province: one specimen reared from a Larix decidua cone, parasitizing an Asynapta laricis larva (Diptera: Cecidomyiidae) (SKRZYPCZYŃSKA 1978).

\section{Aphanogmus strabus DESSART, 1994 *}

Stawin, West Pomeranian (Zachodniopomorskie) Province: one specimen found on Brassica napus LINNAEUS, 1753 var. napobrassica (LINNAEUS) REICHENBACH, 1833 (DESSART 1994).

\section{Aphanogmus strobilorum BAKKE, 1953}

Forest Inspectorate of Brzesko, Małopolska Province: one specimen reared from a Larix decidua cone, parasitizing an Asynapta laricis larva (Diptera: Cecidomyiidae) (SKRZYPCZYŃSKA 1978). 
Experimental Forestry Unit in Krynica Zdrój, Małopolska Province: an unknown number of specimens reared from Picea abies (LinNAEUS) H. KARSTEN, 1881 (SKRZYPCZYŃSKA 1984).

\section{Aphanogmus tenuicornis THOMSON, 1858}

Forest Inspectorate of Brzesko, Małopolska Province: four specimens reared from Larix decidua cone, parasitizing Asynapta laricis larva (Diptera: Cecidomyiidae). The identification of these specimens cannot have been correct because of the ambiguous original type description (SKRZYPCZYŃSKA 1978).

\section{MEGASPILIDAE}

Dendrocerus aphidum (RONDANI, 1877)

Chylice, Mazowsze Province, Gołkowice, Opole Province and Czechów, Świętokrzyskie Province [As D. bicolor (KIEFFER, 1907)]: overall, 151 specimens of three Megaspilidae species in three localities were found parasitizing Aphidiidae (Hymenoptera) and Charipidae (Diptera) on Medicago sativa LINNAEUS, 1753 cultures (BAŃKOWSKA et al. 1975).

Locality not given: One specimen on Brassica napus and two specimens on Triticum spp. LinNAEUS, 1753 parasitizing Aphidiidae (Hymenoptera) (SOBOTA \& GABRYŚ 1999).

Skierniewice, Łódź Province [as D. bicolor (KIEFFER, 1907)]: one specimen found on Crataegus sp. LinNAEUS, 1753 bordering an apple orchard (OLSZAK 1992).

Skierniewice, Łódź Province [as D. breadalbimensis (KIEFFER, 1907)]: one specimen found on Euonymus sp. LiNNAEUS, 1753 bordering an apple orchard (OLSZAK 1992).

\section{Dendrocerus carpenteri (CURTIS, 1829)}

Chylice, Mazowsze Province, Gołkowice, Opole Province and Czechów, Holy Cross Province: overall, 151 specimens of three Megaspilidae species in three localities were found parasitizing Aphidiidae (Hymenoptera) and Charipidae (Diptera) on Medicago sativa cultures (BAŃKOWSKA et al. 1975).

Huta Gruszczyno, Mazowsze Province: three specimens found as hyperparasitoids of Aphis acetosae LINNAEUS, 1761 (Hemiptera: Aphididae) (HAWRO \& CERYNGIER 2006).

Bydgoszcz, Kujawsko-Pomorskie Province: 272 specimens found as hyperparasitoids of Aphis fabae cirsiiacanthoidis SCOPOLI, 1763 (Hemiptera: Aphididae) on Philadelphus coronarius LINNAEUS, 1753 (BARCZAK \& BŁAŻEJEWSKA 1992).

Las Piwnicki Nature Reserve and Dziki Ostrów Nature Reserve, Kujawsko-Pomorskie Province: found as parasitoids of Trioxys pallidus (HALIDAY, 1833) (Hymenoptera: Braconidae), hyperparasitoids of Tuberculoides annulatus (HARTIG, 1841) (Hemiptera: Aphididae) (BARCZAK 1994). 
Łomianki and Dziekanów Leśny, Mazowsze Province: found as hyperparasitoids of Rhopalosiphum padi (LinNAEUS, 1758) (Hemiptera: Aphididae) and Sitobion avenae (FABRICIUS, 1775) (Hemiptera: Aphididae) (PANKANIN-FRANCZYK \& CERYNGIER 1999).

Locality not given: 20 specimens on Brassica napus and 32 specimens on Triticum spp. parasitizing Aphidiidae (Hymenoptera) (SовOTA \& GABRYŚ 1999).

Łomianki, Mazowsze Province: 173 specimens found on Hippophae rhamnoides LINNAEUS, 1753 hyperparasitizing Capitophorus hippophaes WALKER, 1852 (Hemiptera: Aphididae); 19 specimens found on Padus avium MILLER, 1768 hyperparasitizing Rhopalosiphum padi (LINNAEUS, 1758) (Hemiptera: Aphididae); 30 specimens found on Phragmites australis (CAVANILLES) TRINIUS ex STEUDEL, 1799 hyperparasitizing Hyalopterus pruni (GEOFFROY, 1762) (Hemiptera: Aphididae); 254 specimens found on Avena sativa LINNAEUS hyperparasitizing Sitobion avenae (FABRICIUS, 1775) (Hemiptera: Aphididae) (CER YNGIER \& PANKANIN-FrANCZYK 2001).

Midfield thickets around Bydgoszcz, Kujawsko-Pomorskie Province: 108 specimens reared as hyperparasitoids from Aphis fabae SCOPOLI, 1763 (Hemiptera: Aphididae) colonies on Chenopodium sp. LINNAEus, 1753 (BARCZAK \& DĘBEK-JANKOWSKA 2001).

Łomianki, Mazowsze Province: 1090 specimens reared as hyperparasitoids from Sitobion avenae (Hemiptera: Aphididae) (CERYNGIER \& PANKANIN-FRANCZYK 2003).

Skierniewice, Łódź Province: one specimen found on Caragana sp. FABRICIUS bordering an apple orchard (OLSZAK 1992).

Grabówko, Kujawsko-Pomorskie Province: 4 specimens reared as hyperparasitoids of Aphis fabae SCOPOLI, 1763 (Hemiptera: Aphididae) living on Euonymus europaea LINNAEUS, 1753 (BARCZAK et al. 1999).

\section{Dendrocerus laticeps (HEDICKE, 1929) *}

Pawłowice, Lower Silesian (Dolnośląskie) Province: found as a hyperparasitoid on winter wheat Triticum sp. (GABRYŚ \& SOBOTA 1991).

Oleśnica Mała and Pawłowice, Lower Silesian (Dolnośląskie) Province: found as a hyperparasitoid on winter wheat Triticum sp. (SовотA 1992).

Łosiów, Opole Province: one specimen reared from the mummy of an aphid feeding on maize Zea mays LiNNAEUS, 1753 (KRAWCZYK et al. 2009).

\section{Dendrocerus pupparum (BOHEMAN, 1832)}

Chylice, Mazowsze Province, Gołkowice, Opole Province and Czechów, Świętokrzyskie Province [as D. puparum (BoHEMAN, 1832)]: overall, 151 specimens of three Megaspilidae species in three localities were found parasitizing Syrphidae (Diptera: Brachycera) (BAŃKOWSKA et al. 1975). 


\section{Lagynodes pallidus (BOHEMAN, 1832) *}

Forest Inspectorate of Jędrzejów, Świętokrzyskie Province: two females reared from a puparium of Apanteles congestus (NEES VON ESENBECK, 1834) (Hymenoptera: Braconidae), which was parasitizing Eurois occulta (LINNAEUS, 1758) (Lepidoptera: Noctuidae) on Vaccinium myrtillus LINNAEUS, 1753 (KARCZEWSKI 1962). Examination of the Karczewski collection in MIZ confirmed the species' identification.

\section{ACKNOWLEDGEMETNS}

We thank Agnieszka DrABER-MoŃKO and Tomasz HufleJT for giving us access to the KARCZEWSKI collection. We also appreciate the help from Tadeusz BARCZAK, István MIKÓ and Andrew POLASZEK with accessing the literature.

\section{REFERENCES}

AleksEev W.N. 1978. Ceraphronoidea. [in:] V.A. Tryapitsyn (ed.). Bethyloidea, Chalcidoidea, Proctotrupoidea, Ceraphronoidea. Keys to the insects of the European part of the USSR. III. Hymenoptera. Part 2. Nauka, Leningrad: 664-691. (in Russian)

Banaszak J., Czechowska W., Czechowski W., Garbarczyk H., SAwoniewicz J., Wiśniowski B. 2000. Threats and perspectives of protection of Hymenoptera. Wiadomości Entomologiczne 18(Supl.2): 177-211. (in Polish)

Bańkowska R., Kierych E., MikoŁajczyk W., Palmowska J., Trojan P. 1975. Aphid-aphidophage community in Alfalfa cultures (Medicago sativa L.) in Poland Part 1. Structure and phenology of the community. Annales Zoologici 32(14): 299-346.

BARCZAK T. 1994. The parasitoid guild of Tuberculoides annulatus (HTG) (Homoptera: Phyllaphididae) on leaves of the brown oak, Quercus robur L. Polskie Pismo Entomologiczne 63(1/2): 157-168. (in Polish)

Barczak T., Bennewicz J., Kaczorowski G., DęBek-Jankowska A. 1999. Parasitic Hymenoptera associated with aphids (Homoptera: Aphidodea) in midfield thickets. Wiadomości Entomologiczne 18(1): 33-39. (in Polish)

BarcZaK T., BŁAŻEJewsKa A. 1992. Parasitoid complex of the aphid Aphis fabae cirsiiacanthoidis SCOP. on garden syringa Philadelphus coronarius L. Acta Universitatis Nicolai Copernici, Nauki Matematyczno-Przyrodnicze, Biologia 39(78): 35-40. (in Polish)

Barczak T., DęBek-Jankowska A. 2001. Pigweed (Chenopodium sp.) as a reservoir of aphid parasitoids. Aphids and Other Homopterous Insects 8: 345-354.

Broad G., Livermore L. 2014. Checklist of British and Irish Hymenoptera - Ceraphronoidea. Biodiversity Data Journal 2: e1167.

Ceryngier P., Pankanin-Franczyk M. 2001. Parasitoid communities of aphids on cereal fields and on wild plants in their neighbourhood. Aphids and Other Homopterous Insects 8: 355-364. 
Ceryngier P., PANKANin-FrancZyK M. 2003. Aphids and their parasitoids on spring wheat crop in the vicinity of Warsaw. Aphids and Other Hemipterous Insects 9: 5-16.

COOPER K.W., DesSART P. 1975. Adult, larva and biology of Conostigmus quadratogenalis DeSSART \& COOPER sp.n. (Hym., Ceraphronoidea), parasite of Boreus (Mecoptera) in California. Bulletin annuel de la Société Royale Belge d'Entomologie 111: 37-53.

CZAJKOWSKA M. 1978. Investigations on the brassica pod midge (Dasyneura brassicae WiNN.). IV. Species composition and importance of parasites. Roczniki Nauk Rolniczych Seria E (Ochrona Roślin) 8(2): 159-175. (in Polish)

Dessart P. 1987. Revision des Lagynodinae (Hymenoptera Ceraphronoidea Megaspilidae). Bulletin de l'Institut Royal des Sciences Naturelles de Belgique Entomologie 57: 5-30.

DessaRT P. 1994. Hymenoptera Ceraphronoidea nouveaux ou peu connus. Bulletin de l'Institut Royal des Sciences Naturelles de Belgique Entomologie 64: 49-103.

Dessart P., Bournier A. 1971. Thrips tabaci Lindman (Thysanoptera) hôte inattendu d' Aphanogmus fumipennis (THOMSON) (Hym. Ceraphronidae) Bulletin annuel de la Société Royale Belge d'Entomologie 107: 116-118.

Evans G.A., Dessart P., GlenN H. 2005. Two new species of Aphanogmus (Hymenoptera, Ceraphronidae) of economic importance reared from Cybocephalus nipponis (Coleoptera, Cybocephalidae). Zootaxa 1018: 47-54.

FERGUSSON N.D.M. 1980. A revision of the British species of Dendrocerus RATZEBURG (Hymenoptera: Ceraphronoidea) with a review of their biology as aphid hyperparasites. Bulletin of The British Museum, Natural History, Entomology 41(4): 255-314.

GABRYŚ B., SOBOTA G. 1991. Comparison of species composition of hyperparazytoids of aphids feeding on neighboring crops of mustard and wheat. [in:] E. CicHOCKA, W. GoszCZYŃsKi (eds). Aphids - their bionomy, harmfulness and natural enemies. Polska Akademia Nauk, Warszawa, 115-118. (in Polish)

GARBARCZYK H. 1997. Ceraphronoidea (Hymenoptera). [in:] J. RAZOwSKI (ed.). Checklist of Animals of Poland, Vol. 5. Wydawnictwa Instytutu Systematyki i Ewolucji Zwierząt PAN w Krakowie, Kraków, 131-132. (in Polish)

HALIDAY A.A. 1833. An essay on the classification of the parasitic Hymenoptera of Britain which correspond with the Ichneumones minuti of Linnaeus. Entomological Magazine 1: 259-276; 333350; 480-491; 2: 93-106, 225-259, 458-468; 3: 20-45, 121-147; 4: 38-59, 92-106, 203-221; 5: 209-248. (in Latin)

Hawro V.A., Ceryngier P. 2006. Ant attendance and parasitization by parasitoids in Aphis acetosae L. Aphids and Other Hemipterous Insects 12: 41-53.

Hellén W. 1966. Fauna Fennica 20. Die Ceraphroniden Finnlands (Hymenoptera: Proctotrupoidea). Societas pro Fauna et Flora Fennica, Helsinki.

JOHNSON N.F. 2015. Hymenoptera Name Server version 1.5. Internet: http://osuc.biosci.ohiostate.edu/ (accessed 29 March 2015).

KARCZEWSKI J. 1962. The importance of bog bilberry (Vaccinium myrtillus L.) for the forest entomocoenosis. Folia Forestialia Polonica Seria A - Leśnictwo 9: 1-192. (in Polish)

KIEFFER J.J. 1914. Das Tierreich 42. Serphidae et Calliceratidae. R. Friedländer and Sohn, Berlin. 
KraWCZYK A., HuREJ M., JACKOWSKI J. 2009. Hyperparasitoids of aphids on maize in Opole region in Poland. Polish Journal of Entomology 78(2): 161-168.

Luhman J.C., Holzenthal R.W., KJAERANDSEn J.K. 1999. New host record of a ceraphronid (Hymenoptera) in Trichoptera pupae. Journal of Hymenoptera Research 8(1): 126.

MASNER L., DeSSART, P. 1967. La reclassification des categories taxonomiques superieures des Ceraphronoidea (Hymenoptera). Bulletin de l'Institut Royal des Sciences Naturelles de Belgique Entomologie 43(22): 1-33.

Mikó I., DeAns A.R. 2009. Masner, a new genus of Ceraphronidae (Hymenoptera, Ceraphronoidea) described using controlled vocabularies. Zookeys 20: 127-153.

OATMAN E.R. 1985. Aphanogmus floridanus, a primary parasite [sic!] of Feltiella acarivira, a predator of spider mites on strawberry (Hymenoptera: Ceraphronidae; Diptera: Cecidomyiidae). Proceedings of the Entomological Society of Washington 87(4): 714-716.

OLSZAK R.W. 1992. Hymenopteran parasitoids (Hymenoptera - Parasitica) of apple orchads - the occurrence and role in reducing pests. Instytut Sadownictwa i Kwiaciarstwa w Skierniewicach, Skierniewice. (in Polish)

PankANin-FranczyK M., CeRYNGieR P. 1999. On some factors affecting the population dynamics of cereal aphids. Aphids and Other Homopterous Insects 7: 289-295.

PARNELl J.R. 1963. Three gall midges (Diptera: Cecidomyidae) and their parasites found in the pods of broom (Sarothamnus scoparius (L.) WIMMER). Transactions of the Royal Entomological Society of London 115(10): 261-275.

PolaszeK A. 2015. Ceraphronidae. [in:] Fauna Europaea version 2.6. Internet: http://www.faunaeur. org (accessed 29 March 2015).

PRIESNER H. 1936. Aphanogmus steinitzi spec. nov., ein Coniopterygiden-Parasit (HymenopteraProctotrupoidea). Bulletin de la Société Entomologique d'Egypte 20: 248-251.

PSCHORN-WALChER H. 1956. Aphanogmus nigrifornicatus nov. spec. (Proctotrupoidea, Ceraphronidae) ein Parasit der räuberisch an Adelgiden lebenden Gallmückenlarven von Aphidoteles thompsoni MoEHN. Mitteilungen der Schweizerischen Entomologischen Gesellschaft 29(4): 353-362.

SCHMitT G. 2004. Parasitoid communities (Hymenoptera) in the agricultural landscape: effects of land use types and cultivation methods on structural parameters. $\mathrm{PhD}$ thesis. Technische Universität Dresden, Dresden.

SKRZYPCZYŃSKA M. 1974. Materials for becoming acquainted with the entomofauna of cones of the European larch (Larix decidua Mill.) and the Polish larch (Larix polonica RAC.). Acta Zoologica Cracoviensia 19(15): 327-336. (in Polish)

SKRZYPCZYŃSKA M. 1978. A review of insects found in the cones of the European larch, Larix decidua MiLl. and Polish larch L. polonica RAC. in Poland. Polskie Pismo Entomologiczne 48(3): 543-563. (in Polish)

SKRZYPCZYŃSKA M. 1984. An attempt at establishing a correlation between the entomofauna of cones in Norway spruce Picea abies (KARST.) and habitat, direction of slope and stand density. Sylwan 128(6): 39-49. (in Polish)

Sовота G. 1992. Parasitoids of cereal aphids on winter wheat in the vicinity of Wrockaw, Poland. Aphids and Other Homopterous Insects 3: 83-88. 
Sobota G., Gabryś B. 1999. Aphidiidae and their parasitoids caught in traps containing aphid sex pheromones. Aphids and Other Homopterous Insects 7: 305-312.

ULRICH W. 1999. The number of species of Hymenoptera in Europe and assessment of the total number of Hymenoptera in the world. Polskie Pismo Entomologiczne 68(2): 151-164.

ULRICH W. 2001. Hymenopteren in einem Kalkbuchenwald: Eine Modellgruppe zur Untersuchung von Tiergemeinschaften und ökologischen Raum-Zeit-Mustern. Schriftenreihe A des Forschzentrum für Waldökosysteme 171: 1-203.

UlRICH W. 2005. Die Hymenopteren einer Wiese auf Kalkgestein: Ökologische Muster einer lokalen Tiergemeinschaft. Schriftenreihe A des Forschzentrum für Waldökosysteme 195: 1-203.

Zeman V., VANĚK J. 1999. Hymenoptera (Braconidae, Ichneumonidae, Eurytomidae, Pteromalidae, Mymaridae, Proctotrupidae, Diapriidae, Scelionidae, Platygasteridae, Ceraphronidae, Megaspilidae, Crabronidae) in terrestial traps in montane and sub-alpine zone in the Giant Mts. Opera Corcontica 36: 171-179.

Received: 12 July 2015

Accepted: 18 August 2015 